\title{
Voluntary disclosure of internal control and auditor's attestation: evidence from China
}

\author{
Fang Lou', Qian Sun ${ }^{2^{*}}$ and Hongqi Yuan ${ }^{2}$
}

\author{
* Correspondence: \\ sunqian@fudan.edu.cn \\ ${ }^{2}$ School of Management, Fudan \\ University, Shanghai 200433, China \\ Full list of author information is \\ available at the end of the article
}

\begin{abstract}
We examine what determines a firm's decision to disclose a self-assessment report on its internal control (IC) system and to further attain an auditor's attestation on the report, using a sample of firms from the Shanghai Stock Exchange during the period 2006-2010. We hypothesize and find supporting evidence that the likelihood of having voluntary disclosure of IC self-assessment with an auditor's attestation is positively related to future equity refinancing, mutual-fund shareholding, and whether the firm is controlled by the government, especially the central government. Our study also takes the identification problem into consideration, as our sample includes firms with IC weaknesses/deficiencies. Our study not only makes an incremental contribution to the literature, but also has practical implications, especially for regulators and investors in China.
\end{abstract}

Keywords: Internal control, Voluntary disclosure, Auditor's attestation, Self-assessment JEL classification: M48, G34

\section{Introduction}

Internal control (IC) disclosure in corporate financial reporting is of considerable interest to both the academic and business communities, particularly following the passing of the Sarbanes-Oxley Act (SOX). Nevertheless, few studies have examined the management incentives of IC reporting. According to Leone (2007), this is partly because most prior research has been conducted in an environment of mandated IC disclosure, not voluntary IC disclosure. There are some exceptions. Bronson et al. (2006) examine the association between firm characteristics and voluntary IC disclosure. Deumes and Knechel (2008) do examine incentives for voluntary IC disclosure. Lin and Rao (2009) study the determinants of disclosing an auditor's attestation of an IC report using only one year (2007) data. Fang et al. (2009) also discuss IC disclosure but without discussing the IC self-assessment report and the auditor's attestation.

Using a unique dataset from the Shanghai Stock Exchange (SSE) during the period 2006-2010, we examine not only why firms would choose voluntarily to disclose their IC self-assessment reports, but also why some of these firms prefer, in addition, to have an auditor's attestation on these reports, a new aspect of the literature. Owing to the fact that no IC weakness/deficiency is reported in their voluntary IC disclosure samples, all the previous authors do not address the identification problem; that is,

(c) The Author(s). 2017 Open Access This article is distributed under the terms of the Creative Commons Attribution 4.0 International License (http://creativecommons.org/licenses/by/4.0/), which permits unrestricted use, distribution, and reproduction in any medium, provided you give appropriate credit to the original author(s) and the source, provide a link to the Creative Commons license, and indicate if changes were made. 
whether independent variables explain the presence/absence of IC weakness, or the presence/absence of disclosure, or both. With Chinese data, we can identify firms with IC weaknesses and therefore better examine the incentives and determinants of voluntary IC reporting and the option of including an auditor's attestation on the report. This also distinguishes our study from the existing literature.

The SSE required its listed firms to establish an IC system and disclose an IC report as of 2006. However, firm management has full discretion in releasing IC information due to the lack of minimum requirements. For example, some firms report their ICs very briefly, with a statement such as "The IC system generally met the 2006 guidelines," whereas others provide detailed explanations of specific risk management, such as management control over subsidiaries, accounts receivable, accounts payable, etc. Some even provide an IC self-assessment with an external auditor's attestation in the report. During our sample period, about $17.3 \%$ of SSE-listed firms voluntarily disclosed self-assessments with an auditor's attestation and $12.7 \%$ only disclosed self-assessments in their IC reports. Self-assessment is important, as it reflects the board of directors' (BoD) view of the firm's IC system and its disclosure may make the firm legally liable. Hence, voluntary disclosure in this study refers to the circumstances when a firm voluntarily discloses self-assessment in its IC report, not just the release of the IC report as generally required by the SSE. ${ }^{1}$ The auditor attestation reflects an auditor's view of the firm's self-assessment report, which can enhance the credibility of the report if the auditor agrees with the BoD on self-assessment. According to the Ministry of Finance's (MOF) interpretation of IC standards, issued in 2010, the self-assessment and auditor attestation are of particular importance in making the IC system effective in China.

No SSE firm had disclosed any IC weakness/deficiency in their IC reports up to 2008. However, the China Securities Regulatory Commission (CSRC) required that all listed firms must disclose IC weaknesses in their IC report if they had had any since 2009. It is worth noting that the mandatory disclosure of self-assessment in the IC report for all listed firms would not start until 2012. ${ }^{2}$ Hence, in our latter sample period 2009-2010, the disclosure of IC self-assessment and auditor's attestation is still voluntary, although some firms did report IC weaknesses. This unique feature of the data allows us to address identification problems when studying the determinants of the voluntary IC disclosure and the decision to attain in addition an auditor's attestation.

Healy and Palepu (2001) point out that the main purpose of the voluntary disclosure of IC reports is to reduce information asymmetry and agency costs. From this, we can infer that attaining an auditor's attestation can make IC disclosure more convincing and therefore further reduce information asymmetry and agency costs. Specifically, we argue that government ownership, institutional holdings, and seasoned equity offerings (SEOs) are the major determinants of the decision to have an auditor's attestation on IC disclosure in China.

A unique feature of listed firms in China is that the government is the controlling shareholder in a large percentage of listed firms. This should have a significant impact on IC disclosure and whether the firm chooses to attain an auditor's attestation. Firstly, the Chinese Government may pursue objectives other than maximizing profit, which exacerbates agency problems between the controlling shareholder and small shareholders. As a grabbing hand, the government may prefer less transparency. However, the government also wants to revitalize SOEs and would like to have their partially 
privatized companies operate according to international norms (see Sun et al. 2013). In the past 30 years, the government, especially the central government, has been the major force in pushing forward SOE reform including privatization to establish a "modern enterprise system." Building up a sound IC system and disclosing IC information is part of such government efforts. Secondly, the government may not be an effective monitor, as it is often represented by officials or government agencies with various opportunistic tendencies, which worsens the traditional agency problem between managers and shareholders. The disclosure of IC self-assessment with an auditor's attestation is very likely in the government's interests as it can reduce information asymmetry and therefore reduce the public concern for controlling shareholder expropriation on the one hand, and mitigate the ineffective-monitoring problem associated with government ownership on the other. This can boost market confidence in listed SOEs and attract more private investors. Hence, we argue that SOEs in China are more likely to disclose an IC self-assessment report with an auditor's attestation than nongovernment controlled firms.

Many authors ${ }^{3}$ have pointed out that different types of government ownership in China can have different impacts on corporate governance, cash-dividend payments, etc. Therefore, we also examine whether there is a difference in the impact on IC disclosure when the central or local government is the controlling shareholder. It is likely that central-government-controlled firms have more incentive than localgovernment-controlled firms to disclose IC self-assessment as the disclosure itself is encouraged by the central government. It is natural that the central government uses its directly controlled firms to showcase good corporate governance. It is also understandable that the managers of these firms are more likely to comply as their promotion depends heavily on how effectively they can carry out central government directions. Local-government-controlled SOEs care more about their local governments' needs and wants, which may deviate from those of the central government. For example, local governments have to shoulder a variety of local social responsibilities such as employment and social welfare in their jurisdictions (Lin et al. 2004). Hence, local government leaders have a strong incentive to pressure managers of localgovernment-controlled firms to pursue local interests rather than carrying out central government decisions when there is a conflict. Consistent with this prediction, prior research shows that local-government-controlled firms are more prone to overinvestment, managing earnings (Chen et al. 2008), having excess employees on their payrolls (Zeng and Chen 2006), executing related party transactions that hurt minority shareholders' interests (Cheung et al. 2010; Jiang et al. 2010), and having worse financial reporting quality (Chen et al. 2009).

Besides government ownership, a firm's IC reporting decision may be affected by institutional shareholders. For example, Bronson et al. (2006) argue that institutional shareholder ownership is positively related to voluntary IC reporting. However, Deumes and Knechel (2008) argue that, because institutional shareholders can effectively mitigate information asymmetry and agency problems, there is no need for further disclosure of IC reports. Hence, there should be a negative relationship between institutional ownership and voluntary IC disclosure. Given that most listed firms in China have a big controlling shareholder, be it the government or a family, we believe that IC disclosure can help not only small individual investors, but also institutional investors, 
to resist controlling shareholder expropriation. Hence, we expect a positive relationship between institutional ownership and voluntary IC disclosure with an auditor's attestation.

We are particularly interested in examining how mutual-fund shareholding would affect voluntary IC disclosure and audit attestation. The Chinese stock market used to be dominated by individual investors. Up until 2001, there were very few mutual funds in China. In 2004 mutual funds held around 5\% of tradable shares in the market, but this increased dramatically, to around $8 \%$ of all shares, in 2010. ${ }^{4}$ Unlike block shareholders (legal persons), mutual funds are financial institutional investors and are usually not represented on the board, owing to their relatively smaller holding size compared with legal persons. However, mutual funds are more active in the market, and their decision to buy or sell shares affects share prices more often. Therefore, not only do mutual funds prefer companies to be more transparent, firm managers also have the incentive to cater to mutual funds by voluntarily releasing IC information with an auditor's attestation. This should lead to a positive relationship between mutual-fund shareholding and the likelihood of issuing IC self-assessment reports with an auditor's attestation.

Myers and Majluf (1984) argue that information asymmetry would negatively affect a company when it is attempting to raise new equity capital in the market. Dechow et al. (1996) also suggest that firms issuing securities are more likely to commit fraud. Chen and Yuan (2004) and $\mathrm{Yu}$ et al. (2006) find that Chinese firms widely engaged in earnings management for rights issues up to 2003, which caused a lot of concern among investors. Hence, managers in China should have an incentive to release their IC self-assessments with an auditor's attestation to enhance the credibility of their financial information for seasoned equity offerings (SEOs) in subsequent years.

Our major findings are as follows. First, firms who have the government, especially the central government, as their largest shareholder are more likely to disclose their IC self-assessment with an auditor's attestation, indicating that the Chinese government is under pressure not to take advantage of outside shareholders and to reduce its own agency problems with managers. Second, the more mutual-fund holdings there are, the more likely managers are to release their IC self-assessment with an auditor's attestation, indicating that mutual funds have a positive impact on a firm's transparency in China. Thirdly, firms with external equity-refinancing plans are more motivated to release their IC self-assessment with an auditor's attestation. Fourthly, we find that some firms with IC weaknesses still voluntarily disclose their IC self-assessment and attain an auditor's attestation. Mutual-fund shareholding can explain the choice to have IC disclosure and an auditor's attestation among firms with IC weaknesses. However, for firms disclosing only an IC self-assessment report without an auditor's attestation, government control, mutual fund shareholding, and SEO plans are not determinants for their voluntary disclosure decisions. On the other hand, the traditional determinants documented in previous studies, such as size, leverage, corporate governance variables, etc., do have significant impact on disclosure decisions. These findings have implications not only for China but also for emerging markets and transitional economies. In fact, the finding that equityrefinancing is an incentive to voluntarily disclose an IC report with an auditor's attestation may have implications for all markets. 
The next section briefly reviews the institutional background in China and develops testable hypotheses. Data and research design section details the sample selection and research design, while the empirical findings and additional tests are presented and discussed in Empirical results and Additional tests sections, respectively. Conclusion section concludes.

\section{Background information and hypotheses Background information}

The Chinese government has over the past decade taken a series of measures to strengthen the protection of small investors and bring accounting and regulatory standards close to the international norm.

Share trading in China was dominated by individual investors, as most tradable shares were held by individuals and the market was highly speculative (see Mei et al. 2005). In order to rationalize trading behavior, reduce speculative bubbles, and enhance the monitoring role of market participants, The China Securities Regulatory Commission (CSRC) encouraged financial institutions to set up mutual funds to invest in the stock market. The mutual fund industry was established in 2001. In 2010 mutual funds held more than $8 \%$ of total shares. Since mutual funds were established to enhance corporate governance and reduce speculation in China, it is particularly interesting to see whether mutual-fund ownership is positively related to the voluntary release of IC reports with an auditor's attestation.

Chinese firms have a strong demand for SEOs, including rights issues. In fact, the capital raised via SEOs has been larger than that raised via initial public offerings (IPOs) for most years since 2000. To regulate SEOs, the CSRC set out some requirements that a firm must meet before it can have an SEO. For example, firms must have a return on equity (ROE) greater than $6 \%$ and have paid cash dividends for the previous three years. Prior studies (see Chen and Yuan 2004; Yu et al. 2006; Chen et al. 2008) provide evidence that publicly traded firms in China engage in earnings management to meet the CSRC requirement for SEOs. Since investors as well as regulators are concerned about earnings management, good firms should have incentives to disclose relevant information and increase transparency when they plan to have SEOs.

The CSRC designated 2002 as the year of corporate governance. Many firms were punished for not being able to meet the corporate governance standards set by the CSRC. Hence, the cost of noncompliance with the rules and regulations issued by the CSRC greatly increased.

In early 2006, the Ministry of Finance (MOF) announced a new set of "China Accounting Standards" (CAS), which were similar to IFRS. An effective internal control system is essential to successfully implementing CAS, as it helps to ensure the quality of financial reporting and accounting information. In June 2006, SSE issued Guidelines for The Internal Control of Listed Companies (hereafter 2006 Guidelines) which requires all publicly traded companies listed on the SSE to "set up a sound internal control system, ensure the completeness, reasonableness and effectiveness of the internal control system ... and promote the reliability of the information disclosed by the company...." However, no minimum or detailed requirement for the content of IC reporting has been provided. 
In May 2008, The Basic Standard for Enterprise Internal Control (2008 Standard) was issued jointly by five important regulatory agencies. ${ }^{5}$ According to this Standard, publicly listed firms must make IC a part of management compensation and performance appraisals, and perform regular IC self-assessments (but it is not necessary to disclose these self-assessments). In 2010, the CSRC issued several further guidelines for implementing the 2008 Standard. Listed firms were still not mandated to release an IC self-assessment and an auditor's attestation to the public, but they had to disclose IC weaknesses/deficiencies if there had been any since 2009. In 2010, the CSRC mandated all listed firms to disclose their IC self-assessment with an auditor's attestation as of 2012. Hence, the IC self-assessment reports during our sample period (2006-2010) were voluntary, as were auditors' attestations.

Although prior studies have found that voluntary IC reporting provides useful information for financial-statement users regarding their decision making (Hermanson 2000), there are costs associated with the disclosure. The main costs are the potential loss of reputation if the company cannot maintain an effective IC system and the possible legal liabilities related to the reporting if the IC system is not as effective as the report stated. The SSE and CSRC have the authority to punish the listed firms and their management (including board members) if they disclose wrong or misleading information including IC information to the public. Depending on the seriousness of the deceitful disclosure, the SSE can warn, publicly condemn, and fine the responsible persons in the company, or even bar them from taking management positions (including board membership) in any listed companies.

Furthermore, given the interpretation of companies' civil liabilities by China's Supreme Court in 2002, firms are liable if they falsify or disclose incorrect information. More than 40 firms have been sued from 2001 to 2009 owing to the fraudulence of their financial reporting. ${ }^{6}$ Of course, the firms with IC weaknesses may have chosen not to report before 2009. This seems consistent with the observation that no weakness appeared in the IC reports released during 2006-08.

\section{Hypotheses}

Using the above information, we develop testable hypotheses below. In general, firms may choose not to issue an IC self-assessment when they have IC weaknesses. Even without IC weaknesses, firms may choose not to disclose IC self-assessments because of the cost associated with such a disclosure. Only when the benefit of disclosure outweighs the cost will a firm choose to disclose a self-assessment. Our first set of hypotheses concerns the relationship between government ownership and voluntary IC disclosure with an auditor's attestation. With the completion of the split share structure reform (SSSR), the state shares became tradable. Hence, the insurance role of government ownership (nontradable government shares serve as a safety buffer for tradable shares) became less important and investors require firms to be more transparent to offset the perception of increased risk. In addition, the government as the controlling shareholder may be less greedy than families as the controlling shareholders because the government has other objectives to pursue, such as establishing a modern enterprise system and improving the market environment. Furthermore, making firms more 
transparent is also in the interests of the government as it is likely to be an ineffective monitor of managers, owing to capability and incentive problems. There is substantial anecdotal evidence that managers of government-controlled firms abuse their power and misuse company money at the expense of shareholders in China. ${ }^{7}$ To have an effective IC system and to disclose an IC report with an auditor's attestation can make monitoring easier for the government. Finally, there is also increasing pressure on the management of SOEs by the public to behave themselves. ${ }^{8}$ This can explain why the CSRC and other relevant government agencies are enthusiastic to issue and enforce the IC standards. Hence, we have the following hypothesis:

H1a

Ceteris paribus, firms controlled by the government are more likely to issue IC selfassessment reports and to attain an auditor's attestation.

More specifically, government ownership can be classified into local- and centralgovernment ownership. As mentioned earlier, local governments are likely to have their own political and economic interests to pursue. They may be less concerned with establishing a modern enterprise system and bettering the stock market environment. The managers of local-government-controlled firms may cater more to their local government bosses rather than the central government as their promotion and personal benefits depend more on the local government. Local-government-controlled firms have more serious agency problems than the aforementioned central-governmentcontrolled firms. Also, local-government-controlled firms usually have lower profiles compared to central-government-controlled firms and get less national media attention. Therefore local-government-controlled firms have less incentive to voluntarily disclose IC reports and to have an auditor's attestation than central-government-controlled firms do. We thus further hypothesize:

H1b

Ceteris paribus, firms controlled by the central government are more likely to issue IC self-assessment reports and to attain an auditor's attestation than those controlled by local governments.

Our second hypothesis concerns the relationship between institutional, especially mutual-fund, shareholding and voluntary IC disclosure. Bronson et al. (2006) argue that institutional shareholders are tough monitors and thereby require firms to release their IC reports. However, Deumes and Knechel (2008) argue that institutional shareholders are effectively monitors, and therefore can substitute for IC reports. Given that the majority of listed firms have a controlling shareholder in China, we believe IC-report disclosure can help not only individual investors, but also institutional investors, to resist the possibility of controlling shareholder expropriation. Since the institutional investors are non-controlling shareholders and many (such as mutual funds) are even professional investors, they have the incentive to require IC disclosure with an auditor's attestation, especially when firms have IC weaknesses. In fact, they demand a firm to be more transparent when it is perceived to be more risky. Hence, we hypothesize:

H2

Ceteris paribus, firms having more mutual fund shareholding are more likely to disclose IC self-assessment and to have an auditor's attestation.

It is possible that mutual funds use their existing holdings to press the companies to disclose IC self-assessment reports and to have an auditor's attestation. It is also 
possible that mutual funds buy into companies with IC self-assessment disclosure and an auditor's attestation. Either way we should observe a positive association between mutual fund shareholding and the likelihood of IC self-assessment disclosure with an audit attestation. Even if mutual funds just buy into firms with voluntary IC disclosure, this pressures firms to disclose an IC report and have an auditor's attestation.

Our third set of hypotheses is regarding the relationship between voluntary IC reporting with an auditor's attestation and SEOs. When firms plan to raise additional equity in the market, they should have a strong incentive to issue more detailed IC reports and to attain an auditor's attestation, especially when the firm has no IC weakness. With information asymmetry, SEOs can easily be interpreted as a bad signal by the market. In addition, there is evidence of pervasive earnings management associated with SEOs before our sample period (see Chen and Yuan 2004 and Yu et al. 2006). The voluntarily release of IC reports can reduce information asymmetry, curtail agency problems, enhance the credibility of issuers and make SEOs more successful. Attaining an auditor's attestation can further enhance the credibility of IC reports. Therefore, we arrive at the following hypothesis:

H3a

Ceteris paribus, firms having equity-refinancing intentions are more likely to issue IC self-assessment reports and to have an auditor's attestation on the IC report.

Since private firms are generally less transparent and less likely to disclose IC information than government-controlled firms, they have to spend more effort to disclose IC information and make it credible when they plan to raise new equity capital. This is because the government-controlled firm may have done the disclosure even if they do not have an equity refinancing plan. Hence, we further hypothesize:

H3b

When planning to have equity-refinancing in the market, non-government-controlled firms are more likely to issue IC self-assessment reports and to have an auditor's attestation on the IC report than government-controlled firms.

However, H3a and H3b may not hold for firms with IC weaknesses, as they usually do not want to have SEOs under such circumstances.

\section{Data and research design}

The sample of this study consists of all firms listed on the SSE during the period 2006-2010. We obtained all financial and market data from the RESSET and CSMAR Databases. IC information is hand-collected from annual reports.

We started with 4172 firm-year observations during our sample period 2006-2010. ${ }^{9}$ After excluding firms in the financial industry and firms with missing values, our final sample included 3994 firm-year observations. Panel A of Table 1 shows the distribution of sample firms across years. The number of firms with IC self-assessment reports increased dramatically from 47 in 2006 to 351 in 2010. More than half of these firms also attained an auditor's attestation on these reports. Such a sharp increase in the number of voluntary IC disclosures indicates that publicly listed firms and investors in China paid more attention to IC reporting after 2006.

Panel B shows the distribution of firms with IC weaknesses. ${ }^{10}$ In 2009, 53 firms reported IC weaknesses. Among them, 14 voluntarily disclosed their IC self-assessments and seven also had an auditor's attestation. ${ }^{11}$ In 2010, 100 firms reported IC weaknesses 


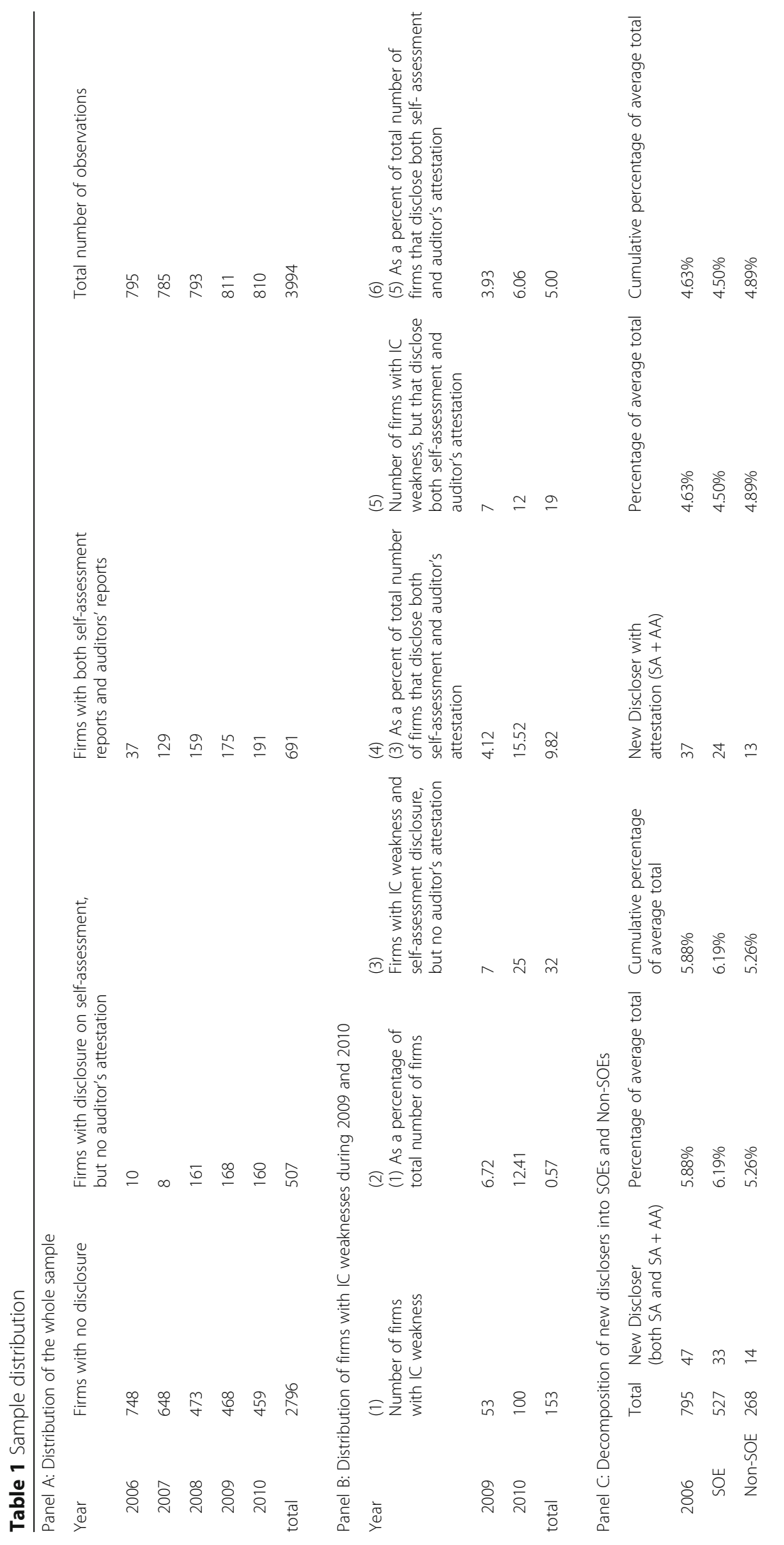




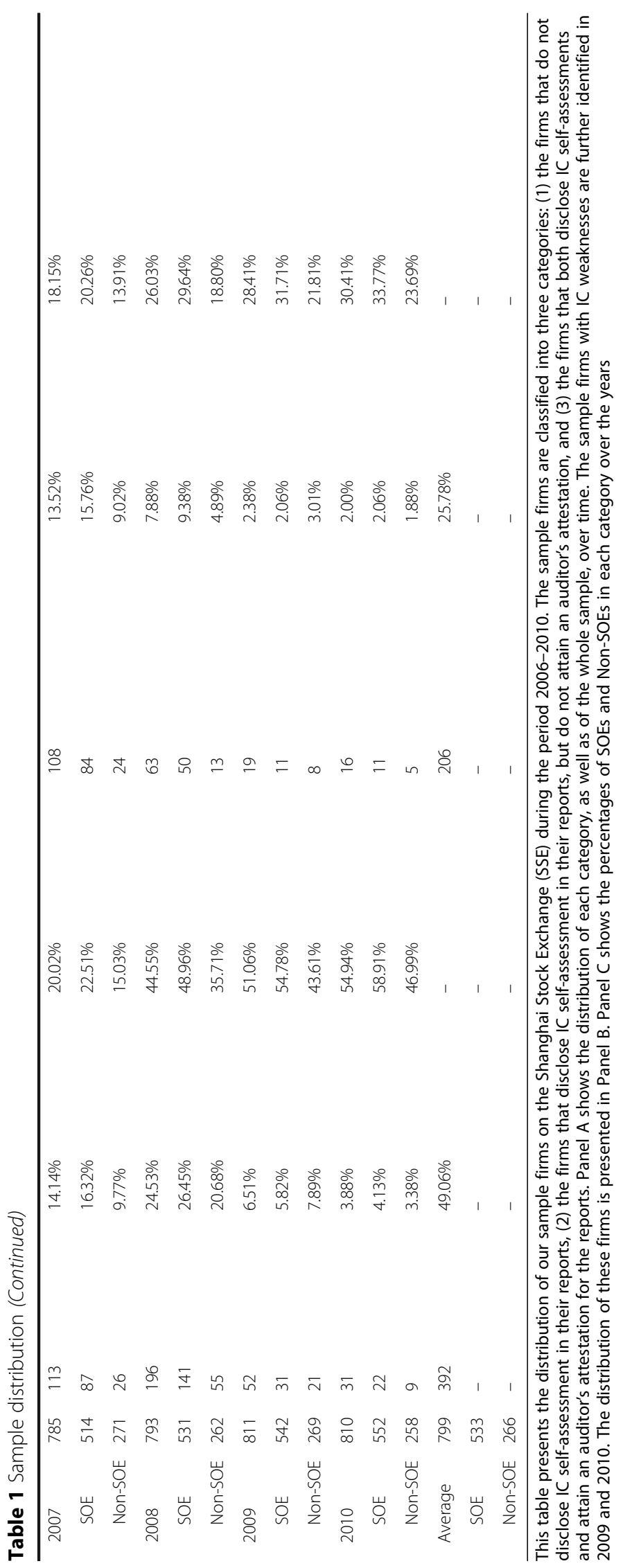


and 37 out of 100 released their IC self-assessments and 12 further attained an auditor's attestation. Hence, a voluntary IC self-assessment reporting and auditor's attestation are not purely a reflection of no IC weakness/deficiency.

Panel $\mathrm{C}$ further divides the firms into SOEs and Non-SOEs in each year. As shown in column 1, there are some variations of the number of SOEs and Non-SOEs over the five-year period due to listing and delisting. On average, there are 533 SOEs and 266 Non-SOEs during our sample period. Column 2 shows the number of SOEs and NonSOEs with disclosure of IC self-assessment reports including those that obtained an auditor's attestation. Columns 3 and 4 present the corresponding percentage and cumulative percentage of SOEs and Non-SOEs in each year. The percentage is computed by dividing the SOEs and Non-SOEs in each cell by the average SOEs and Non-SOEs, respectively. Columns 5-7 present similar statistics for firms with both IC selfassessment disclosure and an auditor's attestation. It is obvious that more SOEs, both in terms of number and percentage, disclose and disclose with an auditor's attestation in the first three years than Non-SOEs, indicating SOEs move to disclose faster and more comprehensively than Non-SOEs. Overall, about $59 \%$ of SOEs had disclosed an IC self-assessment report in 2010, while the percentage for non-SOEs is about $47 \%$. The cumulative proportion of SOEs that both disclose and attain an auditor's attestation was about $34 \%$ in 2010 while non-SOEs was about $24 \%$. This is consistent with our conjecture that firms with government as the controlling shareholder are more likely to disclose an IC self-assessment report and to attain an auditor's attestation.

Since there are a few possible choices for a firm's disclosure decision over time, we use three pooled Logit regression models to test our hypotheses regarding Chinese firms' voluntary disclosure of IC self-assessment reports and attaining an auditor's attestation. The baseline model is specified as follow:

$$
\begin{aligned}
& \text { Logit }\left(I C V D_{i t}\right)=a_{0}+\alpha_{1} S E O_{i t}+\alpha_{2} \text { FUND }_{i t}+\alpha_{3} G O V_{i t}+\alpha_{4} C_{\text {CNTRAL }}^{*} G O V_{i t} \\
& +a_{5} S E O_{i t}{ }^{*} G O V_{i t}+a_{6} S_{I Z E_{i t}}+\alpha_{7} G R O W_{i t}+\alpha_{8} R O E_{i t}+\alpha_{9} L E V_{i t} \\
& +\alpha_{10} I N D I R_{i t}+\alpha_{11} C L I S T_{i t}+\alpha_{12} B I G 4_{i t}+\alpha_{13} I N V_{i t}+\alpha_{14} A G E_{i t} \\
& +\alpha_{15} \text { IndMBR }+ \text { YRDummies }+\varepsilon_{i t}
\end{aligned}
$$

In fact, the three models are otherwise the same except the Logit variable, ICVD, is defined differently. In Model 1 , we set $\operatorname{ICVD}_{i t}$ to 1 if firm i discloses its IC selfassessment report at year $\mathrm{t}$ no matter whether there is an auditor's attestation or not, and zero otherwise. This is to examine the choice between disclosure and no-disclosure or the likelihood to disclose IC self-assessment versus not to disclose. In Model 2, we first exclude all firms that do not disclose an IC self-assessment report in year $t$, then set $\mathrm{ICVD}_{i t}$ to 1 if firm i attains an auditor's attestation to its IC self-assessment report, and zero otherwise. This is to examine the choice between disclosure only and disclosure with an attestation or the likelihood to attain an auditor's attestation among disclosers. Finally in Model 3, we define a Multinomial Logit variable, MLogit (ICVD ${ }_{\text {it }}$ ). Instead of being binary, it is categorized into three groups: ICVD0 represents firms with no IC self-assessment report at all; ICVD1 represents firms with an IC selfassessment report only; and ICVD2 represents firms with both an IC self-assessment report and an auditor's attestation. ICVD0 is used as the benchmark. We replace ICVD 
with ICVD1 and set it equal to 1 if firm $i$ is in the category of ICVD1 in year t, and zero otherwise. Similarly, we replace ICVD with ICVD2 and set it equal to 1 if firm i is in the category of ICVD2 in year $t$, and zero otherwise. The dependent variable, Logit $\left(\mathrm{ICVD}_{i t}\right)$, measures the likelihood of firm i having ICVD1 and ICVD2 in year $\mathrm{t}$. Hence, there are two simultaneously estimated equations in the Multinomial Logit regression model: one examines whether a firm discloses its IC self-assessment report only without attaining an auditor's attestation, and the other examines whether a firm has both a self-assessment disclosure and an auditor's attestation. We also compare the impacts of the same test variable in the two equations of our Multinomial Logit Framework. With these three models, we can examine the likelihood for all the possible decisions regarding disclosure and attaining an auditor's attestation.

Since attaining an auditor's attestation is done merely to make the IC self-assessment report more convincing, we use the same set of independent variables in all models. SEO is a dummy variable proxy for the future SEO plan. The gestation period for a typical SEO is usually between 5 and 10 months if the starting point is set as the board decision date to issue the SEO, although the gestation period for some firms can be longer than a year. Hence, SEO is set equal to 1 if a firm makes SEOs in the next fiscal year, and zero otherwise. FUND ${ }_{\text {it }}$ is defined as the number of shares held by a mutual fund among the top-10 shareholders divided by total number of shares in firm $i$ at the end of year t. GOV is also a dummy variable serving as a proxy for government control. It is equal to 1 if the largest shareholder of the firm is the government (including both central government and local governments), and zero otherwise. CENTRAL is another dummy to further single out the firms controlled by the central government. It is set to 1 if the controlling shareholder is the central government and zero otherwise. These variables are our main test variables. The rest are similar variables used in previous studies as possible determinants for voluntary IC disclosure. Although we use the same set of independent variables to estimate both equations, they may have different impacts in different equations. The definition of all these variables is shown in the Appendix: Table 7.

If our first hypothesis $\mathrm{H} 1$ is correct, then the estimated coefficient for the GOV dummy should be positive and significant, as the government either has incentives or is pressed to force managers to disclose an IC self-assessment report and to attain an auditor's attestation. The interactive term CENTRAL*GOV is included to distinguish the central government from local governments. With this interactive term, we can test H1b, whether central-government-controlled firms are more likely to have IC disclosure with an auditor's attestation than local-government-controlled firms. If $\mathrm{H} 2$ is correct, then the coefficients of FUND should be positive and significant, as the hypothesis says that the mutual funds prefer the firms be more transparent and may force firms to release more IC information. If $\mathrm{H} 3 \mathrm{a}$ is correct, then the estimated coefficient of the dummy variable SEO should be positive and significant, as the plan to raise equity capital in the market gives incentives to voluntarily disclosure the IC self-assessment report and to have an auditor's attestation. The interactive dummy GOV*SEO can further help us to test if the incentive for IC disclosure with an audit attestation is the same for governmentcontrolled and private firms when firms plan to have SEOs.

Following previous studies, we include the natural logarithm of firm size (SIZE), the operating-revenue growth rate (GROW), leverage (LEV), inventory as a percentage of 
total assets (INV), and profitability (ROE) as control variables in our regressions. Both Bronson et al. (2006) and Deumes and Knechel (2008) argue that large firms are more opaque and have the incentive to use IC reports to increase transparency in public, and they also find evidence that firm size is positively related to the likelihood of IC disclosure.

Kinney and McDaniel (1989) and Bronson et al. (2006) argue that rapidly growing firms have IC systems that fail to meet an increase in customer demand or entry into a new market. However, the predicted impact of GROW on IC disclosure could go either way. On the one hand, managers may choose to hide possible IC weaknesses by not disclosing. On the other hand, the investors may strongly demand these firms disclose their IC reports.

Bronson et al. (2006) hypothesize that LEV should have a positive impact on the likelihood of disclosing the IC report as debt holders prefer firms to be more transparent. Deumes and Knechel (2008) argue that LEV, ROE, and INV can affect the inherent risk within a firm. However, their impact on IC disclosure can also go either way. For example, lenders, especially banks, are effective monitors with less information disadvantages, and thus may be a good substitute for IC disclosure. This is likely the case in China as listed firms mainly borrow from banks and the corporate debt market was very small during our sample period.

To control for the possible impact of an alternative corporate-governance mechanism on voluntary IC disclosure, we include in the regression the percentage of independent directors on the board (INDIR), whether the firm is audited by one of the "Big 4" accounting firms (BIG4), and whether the firm is cross-listed in New York (CLIST). It is reasonable to assume that a firm with a higher percentage of independent directors on the board, with a dual-listing in New York or NASQAQ, and with a BIG4 firm as its auditor, should have better corporate governance. However, as argued by Deumes and Knechel, good corporate governance may either be a complement to or substitute for IC disclosure. Deumes and Knechel use dummy variables to control for industry effect, but we use the industry average MBR (IndMBR) instead, as it is more succinct. In addition, we control for the maturity of the firm (AGE) and the year-specific effect (YRDummies).

Since our simple Logit and Multinomial-Logit Regressions use pooled data, we follow Petersen $(2009)^{12}$ to control for time-series dependence by adjusting the standard errors for clustering on each company.

Table 2a presents descriptive statistics for all variables included in our Logit regressions. On average, slightly more than $10 \%$ of firms had SEOs in the next fiscal year during our sample period. The mutual funds investors among the top-10 largest shareholders held an average of $3 \%$ of shares. The government was the largest shareholder in $67 \%$ of the firms. However, the central government was the largest shareholder at $17.2 \%$. Only $7 \%$ of the firms were audited by BIG4, ${ }^{13}$ and the average listing time for a firm is around 9.3 years. All variables show a reasonable dispersion. Table $2 \mathrm{~b}$ shows the mean and medians of our test variables across different groupings of firms with IC weaknesses. For instance, among 153 firms with IC weaknesses, $7.2 \%$ had SEOs planned for the following year; mutual funds on average held $3.2 \%$ of shares. Among 51 firms having IC weaknesses, but also disclosing IC self-assessments, three (5.9\%) had SEOs planned for the 
Table 2 Descriptive statistics for independent variables

\begin{tabular}{llllll}
\hline \multicolumn{5}{c}{ Panel A: Descriptive statistics for full sample during the period of 2006-2010 } \\
& Mean & Q1 & MEDIAN & Q3 & Std. Dev. \\
SEO & 0.106 & 0 & 0 & 0 & 0.308 \\
FUND & 0.030 & 0 & 0.006 & 0.044 & 0.047 \\
GOV & 0.668 & 0 & 1 & 1 & 0.471 \\
CENTRAL & 0.172 & 0 & 0 & 0 & 0.377 \\
SIZE & 3231 & 1362 & 2709 & 6474 & 3666 \\
GROW & 0.338 & -0.017 & 0.139 & 0.326 & 3.047 \\
ROE & 0.066 & 0.025 & 0.072 & 0.128 & 2.607 \\
LEV & 0.602 & 0.397 & 0.541 & 0.672 & 1.161 \\
INDIR & 0.359 & 0.333 & 0.333 & 0.375 & 0.050 \\
CLIST & 0.013 & 0 & 0 & 0 & 0.111 \\
BIG4 & 0.070 & 0 & 0 & 0 & 0.255 \\
INV & 0.177 & 0.062 & 0.138 & 0.237 & 0.161 \\
AGE & 9.349 & 6 & 9 & 13 & 4.023 \\
IndustryMBR & 3.227 & 1.958 & 3.114 & 4.330 & 1.356
\end{tabular}

Panel B: Descriptive statistics of test variables for firms with IC weakness during the period 2009-2010

\begin{tabular}{|c|c|c|c|c|c|c|}
\hline & \multicolumn{2}{|c|}{$\begin{array}{l}\text { Firms with IC weakness } \\
(n=153)\end{array}$} & \multicolumn{2}{|c|}{$\begin{array}{l}\text { Firms with IC weakness, but } \\
\text { which disclose self-assessments } \\
\text { (no auditor's attestation) } \\
(n=51)\end{array}$} & \multicolumn{2}{|c|}{$\begin{array}{l}\text { Firms with IC weakness, but which } \\
\text { disclose both self-assessments and } \\
\text { auditor's attestations } \\
(n=19)\end{array}$} \\
\hline & Mean & Median & Mean & Median & Mean & Median \\
\hline SEO & 0.072 & 0 & 0.059 & 0 & 0.157 & 0 \\
\hline FUND & 0.032 & 0.004 & 0.053 & 0.021 & 0.051 & 0.018 \\
\hline GOV & 0.653 & 1 & 0.667 & 1 & 0.789 & 1 \\
\hline CENTRAL & 0.183 & 0 & 0.294 & 0 & 0.421 & 0 \\
\hline
\end{tabular}

This table presents the descriptive statistics for all independent variables defined in Table 2. Panel A presents the statistics for the full sample period 2006-10, while Panel B presents the statistics of our test variables in the subsample of firms with IC weakness during the period 2009-2010

${ }^{a}$ SIZE in Table 2 (both panels A and B) is the total assets (in million RMB) at year-end.

following year; mutual funds held about 5.3\%. Among the 19 firms with weaknesses, but having both IC disclosure and audit attestation, three (15.7\%) had SEOs planned for the following year; mutual funds held about $5.1 \%$. This means that, even with IC weaknesses, some firms still disclose an IC report with audit attestation and have an equity-refinancing plan.

We have examined the Pearson and Spearman correlation coefficients between all these variables. As shown in Table 3, all correlation coefficients between independent variables are below 0.35, except the one between SIZE and FUND, which is 0.42 (still not too high). Hence, multicollinearity is not a serious problem in our analysis.

\section{Empirical results}

The Logit regression results for the full sample are reported in Table 4. To save space, we do not present year dummies and constants. For Model 1, many variables suggested by previous authors are highly significant. Firstly, as reported in both Bronson et al. (2006) and Deumes and Knechel (2008), the estimated coefficient for SIZE is positive and statistically significant at the $1 \%$ level, 


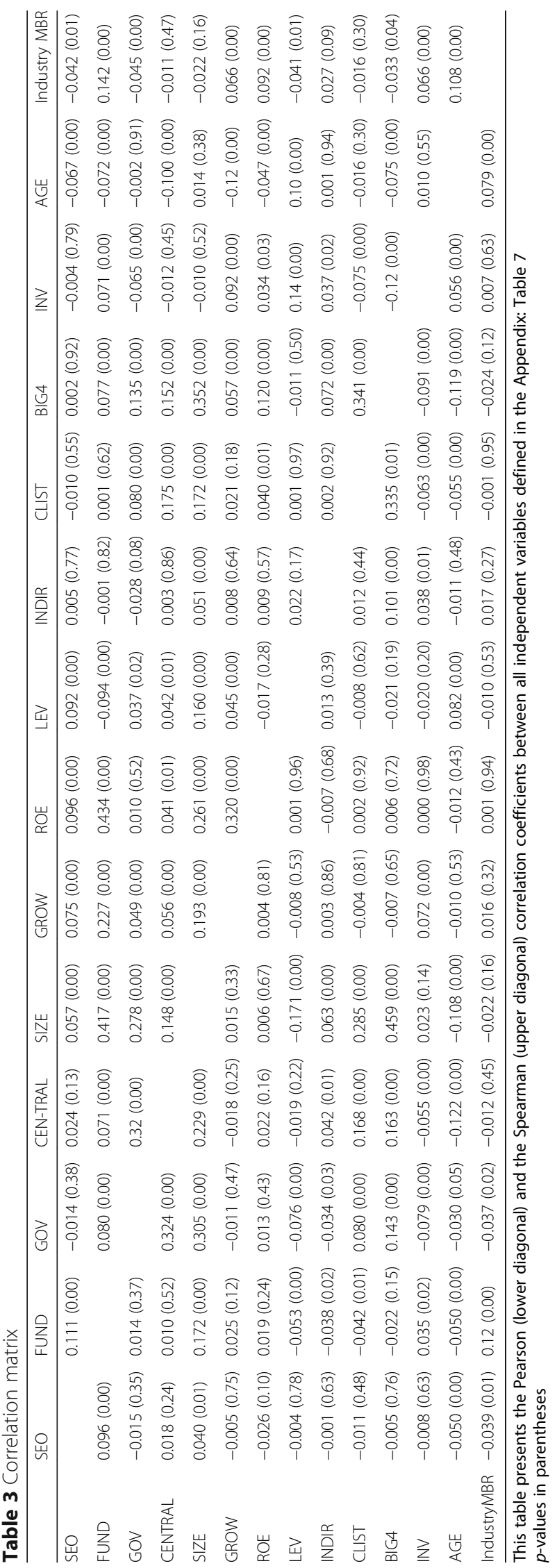




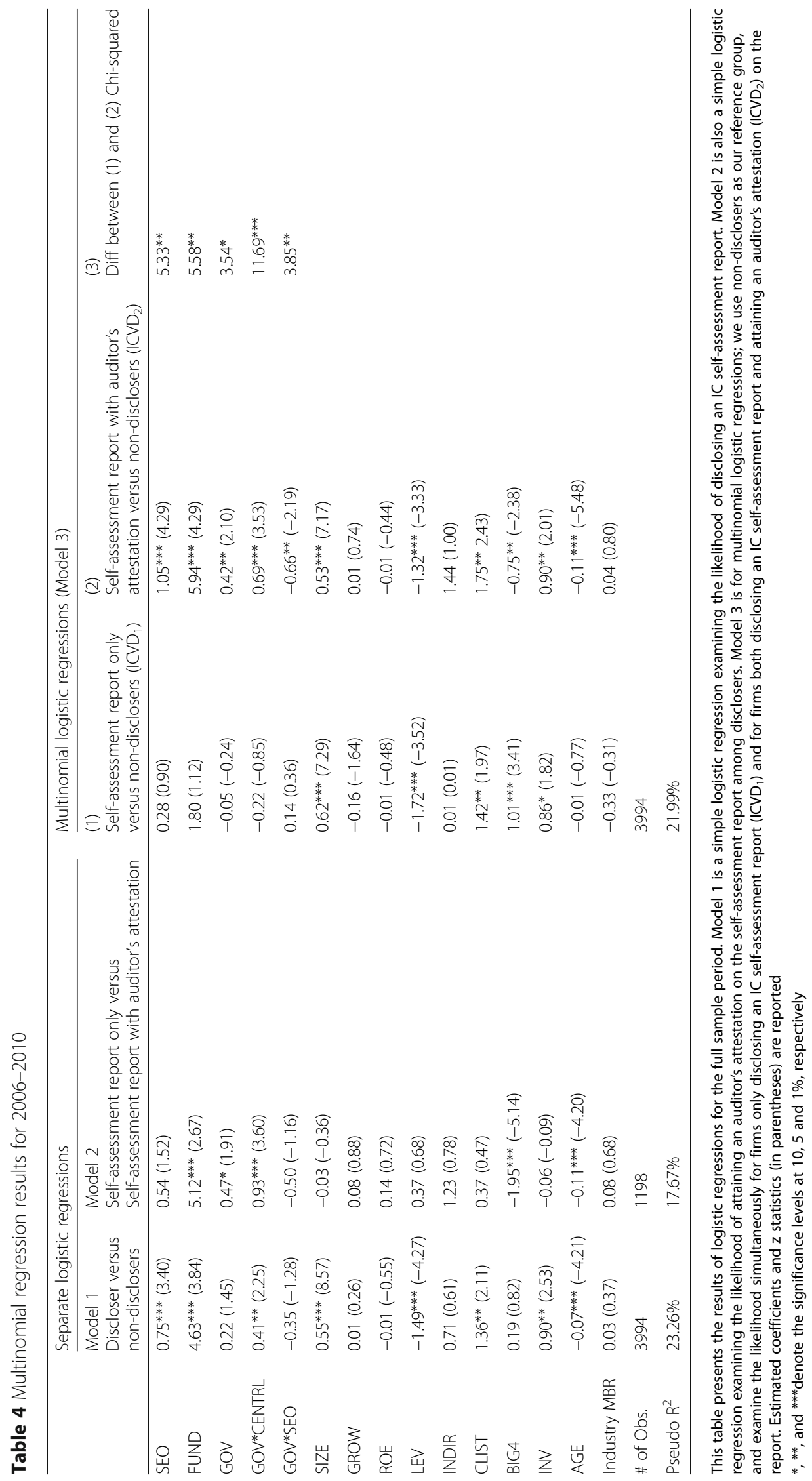


indicating that IC for large firms is more complicated and therefore needs to be disclosed to reduce information asymmetry. Secondly, the estimated coefficient for LEV is negative and significant at the $1 \%$ level, ${ }^{14}$ which is inconsistent with the findings in Deumes and Knechel (2008). However, as argued by the same authors, this is possible, as lenders may provide a monitoring role that can substitute for the disclosure of an IC report. We argue that this is more likely the case in China as the corporate debt market is currently very small. Banks are the major lenders. They have less information asymmetry and more incentive to monitor the firms. Thirdly, the positive and significant estimate for CLIST indicates that firms' crosslistings in New York may have high standards for corporate governance and are more likely to have an IC self-assessment report. Fourthly, the estimated coefficient for INV is positive and significant, suggesting that firms with high inventory levels have an incentive to disclose an IC report in order to reduce information asymmetry. Finally, AGE has a negative and highly significant coefficient, indicating that more mature firms may have long financial records, which makes them subject to less information asymmetry; therefore, they have substitutes, to a certain extent, for IC disclosure.

Now we examine the estimated coefficients for our test variables in Model 1. First, the estimate for GOV is positive but insignificant, which suggests that firms controlled by local governments are not more likely to disclose an IC selfassessment report than private firms. However, as expected, the estimate for GOV*CENTRL is positive and significant at the 5 percent level, indicating that firms controlled by the central government are more likely to release an IC selfassessment report than other firms. These findings lend support to H1b but not H1a. Second, the positive and highly significant estimates for FUND and SEO strongly support our $\mathrm{H} 2$, that mutual funds prefer firms to be more transparent, and $\mathrm{H} 3 \mathrm{a}$, that firms have an incentive to release an IC self-assessment if they have an SEO planned for the following year. Since government-controlled firms are more likely to disclose self-assessments and face less information asymmetry in general, it is possible that private firms have stronger incentives to enhance their transparency when they plan to raise new equity. In that case, the estimate for GOV*SEO should be negative and significant. However, the estimated coefficient for GOV*SEO in Model 1 is insignificant although negative, suggesting that private firms are not necessarily more likely to disclose IC self-assessment reports when they plan to raise new equity, which is inconsistent with our H3b. This finding is robust when we replace GOV*SEO with CENTRL*GOV*SEO. ${ }^{15}$

From Model 2 we see that the estimated coefficients for Fund and Central"GOV are positive and highly significant, and the estimated coefficient for GOV is also positive and marginally significant at the $10 \%$ level. These findings indicate that both government control and mutual fund ownership have positive influences on the likelihood of a firm to further attain an auditor's attestation on the IC selfassessment report among all disclosing firms, which is consistent with our H1a, $\mathrm{H} 1 \mathrm{~b}$, and H2. However, the estimated coefficients for SEO and GOV*SEO are not statistically significant, which is inconsistent with our H3a and H3b. Interestingly, the estimated coefficients for SIZE, LEV, CLIST, and INV which are significant in Model 1 are not significant in Model 2. This suggests that once a firm has 
disclosed its IC self-assessment report, the firm size, leverage, etc. will not affect its decision to attain an auditor's attestation. AGE is still statistically significantly and negatively related to the likelihood of attaining an auditor's attestation. In addition, BIG4 has a negative and significant estimated coefficient in Model 2, suggesting reputable auditors are a substitute for attaining an auditor's attestation for the IC self-assessment report.

We further look at the Model 3 results in columns 3, 4, and 5. As mentioned earlier, our multi-nominal Logit model estimates two equations simultaneously. The first equation as reported in column 3 examines the likelihood of a decision to stay non-disclosing or to only disclose the IC self-assessment report without attaining an auditor's attestation. The second one as reported in column 4 examines the likelihood of a decision to stay non-disclosing or to disclose with an auditor's attestation. From column 3 we see that all estimated coefficients for our test variables are statistically insignificant. This is in contrast with the results in Model 1 where most of the coefficients of our test variables are significant. On the other hand, most other variables which have significant estimated coefficients in Model 1 still have significant coefficients in column 3. In addition, BIG4 and INV are positively and statistically significantly related to the likelihood to disclose an IC self-assessment report without attaining an auditor's attestation. These findings indicate that our test variables may be more related to the likelihood of disclosure with an auditor's attestation rather than pure disclosure of IC selfassessment without attaining attestation. The results reported in column 4 confirm this is the case. Here we see all our test variable estimates are significant and with expected signs. The progressively more positive and significant estimates for GOV and Central*GOV indicate that government-controlled firms are more likely to disclose IC self-assessment reports and to attain an auditor's attestation than private firms, while firms controlled by the central government are even more likely to do so. These findings lend strong support to our H1a and H1b. The positive and highly significant estimate for FUND indicates that mutual fund holdings are positively related to the decision for IC disclosure with an auditor's attestation, which is consistent with $\mathrm{H} 2$. In fact, $\mathrm{H} 2$ has the strongest support from the empirical results as the estimate for FUND is also significant in Models 1 and 2. Although the estimate for GOV*SEO is negative but insignificant as in Models 1 and 2, we find it negative and significant here indicating Non-SOEs are more likely to disclose IC information with an auditor's attestation when they plan to have SEOs. This is consistent with H3b. ${ }^{16}$ Column 5 in Table 5 further shows the test for equality between the estimated coefficients for our test variables in columns 3 and 4. It shows that the estimates for FUND, GOV, CENTRAL*GOV, and GOV*SEO are significantly different between the two equations, which is consistent with the results reported in columns 3 and 4. The estimates of control variables are qualitatively the same as those in Models 1 and 2, and in column 3 .

As pointed out earlier, no firm reported IC weaknesses/deficiencies during the period 2006-2008, but there are firms that reported IC weaknesses/deficiencies during the period 2009-2010. In addition, we find that some firms with IC weaknesses/deficiencies also had SEOs planned for the following year, have the government as their controlling shareholder, and have mutual fund investors among the 


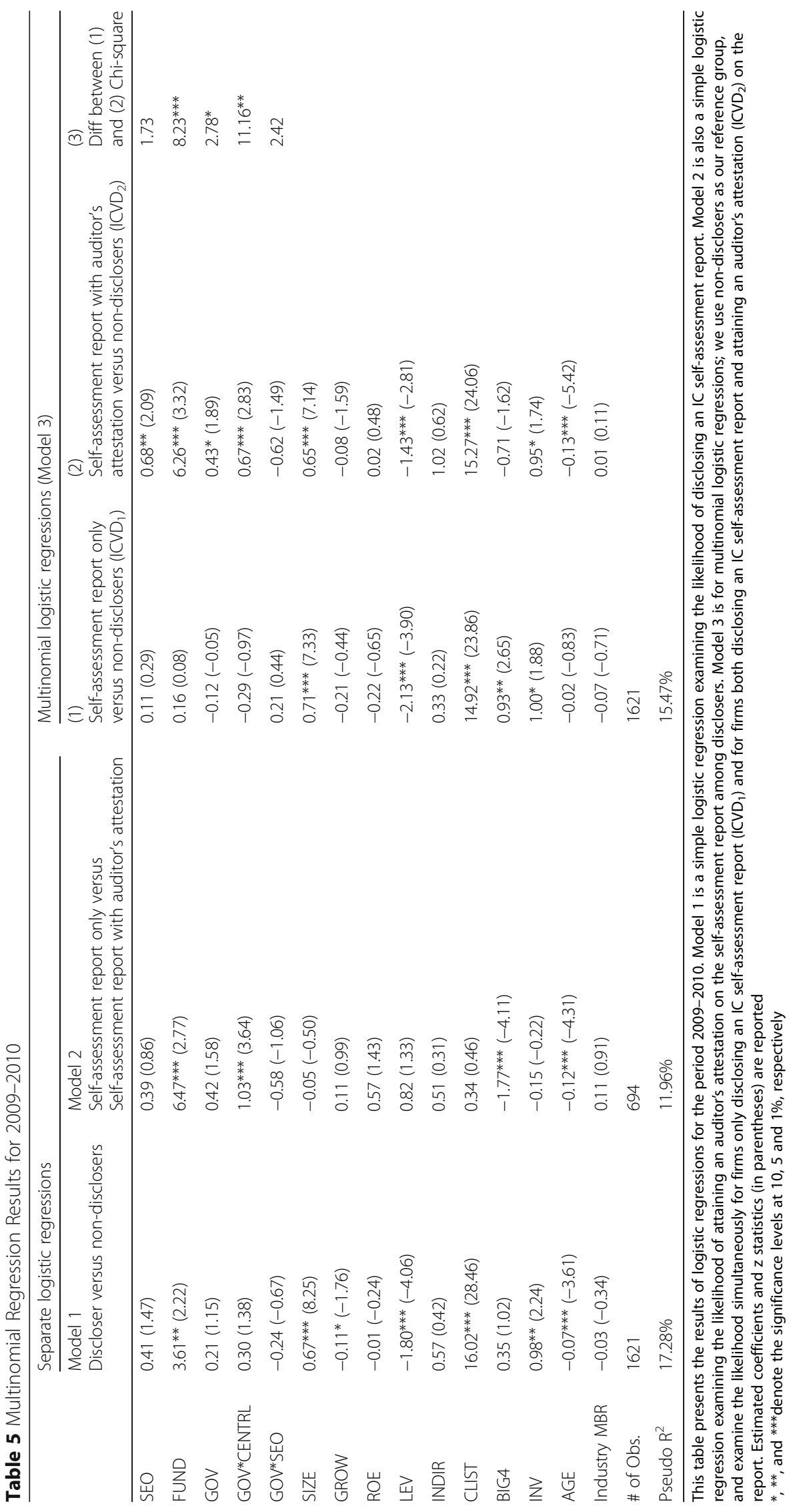


top-10 shareholders. Hence, we used the data in the subsample period 2009-2010 to rerun the same Logit regressions and report the results in Table 5. As shown in the table, the multi-nominal Logit regression results are qualitatively the same as those in Table 5 except SEO*GOV becomes insignificant. The Model 2 results are also similar except that the estimate for GOV becomes insignificant. The Model 1 results are a bit weak as only the FUND estimate stays positive and significant. The estimates for SEO and Central*GOV becomes insignificant. Considered together, these results indicate that SEO, FUND, and CENTRAL*GOV can still explain the disclosure of an IC self-assessment report and attaining an auditor's attestation even when some firms have IC weaknesses.

To further examine the identification problem, we repeat the Logit regressions for the subsample of 153 firms with IC weaknesses reported during the period 2009-2010, and the results are shown in Table 6. The estimated coefficients are somewhat different compared to those reported in Tables 4 and 5. Firstly, the estimate for SEO is negative and significant for both Models 1 and 3. This means that firms with IC weaknesses tend not to disclose IC self-assessment reports and attain auditors' attestations. This is understandable as not many firms would like to have SEOs under such circumstances. Secondly, the estimated coefficient for FUND is positive and highly significant in Model 1 and the first equation in the multi-nominal Logit model (Model 3). The estimated coefficient for FUND in the second equation is positive with a $\mathrm{t}$-value of 1.60 , which is almost significant at the $10 \%$ level. $^{17}$ These findings are generally consistent with our $\mathrm{H} 2$ and lend support to our conjecture that mutual funds are concerned more with the transparency of a firm's IC when the firm has IC weakness/deficiency. Thirdly, the estimated coefficients for GOV and GOV*CENTRAL are insignificant. This means that the government, as the controlling shareholder, wants to use IC disclosure and the associated auditor's attestation to force management to work harder and to meet higher standards; however, when the firm already has IC weaknesses, these government-controlled firms are not more likely to disclose IC information than private firms. Fourthly, the estimated coefficient for GOV*SEO is highly positive and significant in column 2, suggesting that with IC weaknesses, the government-controlled firms are more likely to disclose IC self-assessment reports with an auditor's attestation than private firms if they still plan to have SEOs. This is possible as private firms may not be able to have SEOs in such a situation. Finally, for other variables, SIZE, CLIST, AGE and BIG4 have estimates similar to those reported in previous tables, while LEV and INV become insignificant. On the other hand, GROW is negative and significant in Models 1 and 3, indicating high-growth firms with IC weaknesses are less likely to disclose and to attain an auditor's attestation to the IC report, which is reasonable.

In view of the results presented in Tables 4,5 and 6 , we can conclude that GOV (especially GOV*CENTRAL), FUND, and SEO tend to explain why firms would like to disclose an IC self-assessment report in general and disclose an IC self-assessment report with an auditor's attestation in particular. GOV, Central"GOV, and FUND can also explain why firms with IC disclosure would like to further attain an auditor's attestation, but they do not explain why firms would like to disclose an IC self-assessment report without attaining an auditor's 


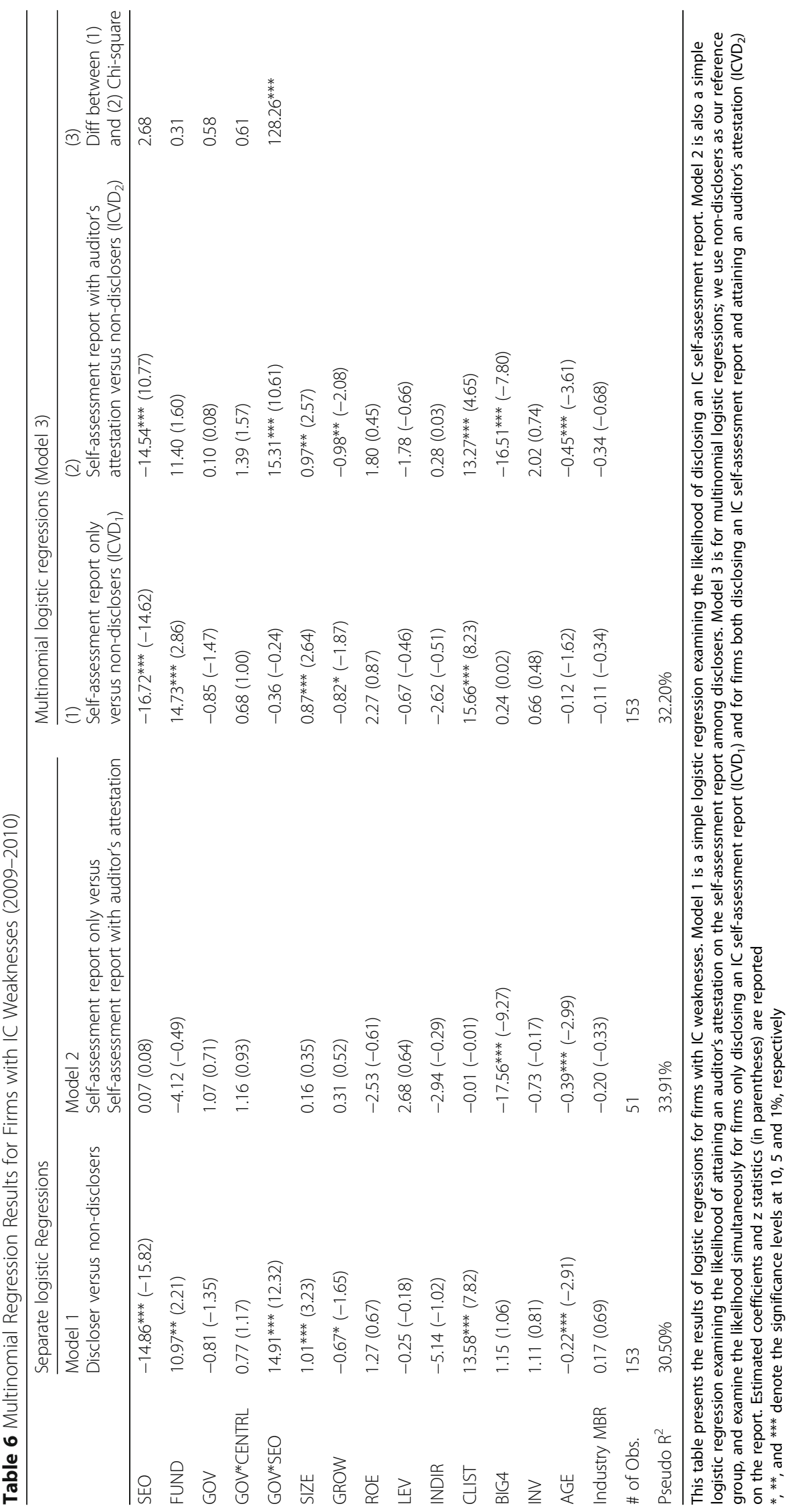


attestation. However, the traditional factors documented in previous studies, such as SIZE, LEV, corporate governance proxies, etc., are still the determinants for the voluntary disclosure of self-assessment reports. They are also the determinants for voluntary disclosure with an auditor's attestation. In addition, GOV, SEO and FUDN can explain the likelihood of disclosure of self-assessment reports and of attaining an auditor's attestation even when some firms have IC weaknesses. Particularly, FUND has the explanatory power for the disclosure of self-assessment reports and for attaining an auditor's attestation for a sub-sample of firms that all have IC weaknesses. This indicates that a firm's IC disclosure decision is not just based on whether the firm has IC weakness or not.

\section{Additional tests}

Some argue that the scale of the SEO may be more relevant to the decision regarding whether to make an IC disclosure and to attain an auditor's attestation. As a robustness check, we replace the SEO dummy with SEOSCALE, which is defined as the SEO proceeds issued by a firm divided by its total assets, and rerun all the regressions. The results are qualitatively the same. We do not include both SEO and SEOSCALE in the same regression, as we find that the correlation coefficient between them is 0.64 , which is also statistically significant at the $1 \%$ level.

It is also possible that firms with poor credibility may choose to attain an auditor's attestation on their reports to enhance their credibility. To look into this possibility, we include an additional dummy variable PENALTY in the regression. PENALTY is set to 1 if the firm has been punished for accounting fraud or information-disclosure irregularities in the previous year, and zero otherwise. Alternatively, we set PENALTY equal to 1 if the firm had a non-clean auditor opinion in the previous year, and zero otherwise. We argue that these firms may have the incentive to hire an auditor to attest to the validity of their IC report. However, the estimated coefficient for PENALTY is unanimously insignificant. ${ }^{18}$

In Tables 4 and 5 , we find that the estimated coefficient for LEV is mostly negative and significant. This is consistent with the argument that debtor monitoring could be a good substitute for IC disclosure. However, it is a fact that SOEs in China have easier access to bank loans than private firms. It is possible that SOEs in general are of better quality. It is also argued that they enjoy de facto loan guarantees from the government. This implies that banks may not monitor these firms closely. If this is true, then LEV should not be a good substitute for IC disclosure as banks may not be effective in mitigating the information asymmetry between the firm and its stakeholders. To investigate this possibility we rerun the regressions by adding an interactive dummy, LEV*GOV. If banks cannot substitute for IC disclosure, then the estimated coefficient for LEV*GOV should be positive and significant. However, we find the estimate is mostly negative and sometimes significant, indicating banks monitor SOEs closely. ${ }^{19}$

Finally, we take a further look at the relationship between FUND and the disclosure decision. Are mutual fund investors leading the disclosures or following the disclosures? A firm's IC disclosure comes out with its annual report. Since the annual report for year $t$ is usually released before April 30 of year $t+1, F U_{N}$ should lead IC disclosure as the mutual fund should know its investment in a 
company at any time. To examine whether mutual funds are leaders or followers, we include $\mathrm{FUND}_{\mathrm{t}+1}$ in our Logit analyses and repeat the regressions. If mutual funds are leaders, then the estimated coefficient for $\mathrm{FUND}_{t}$ should be positive and significant; if they are followers, the estimated coefficient for $\mathrm{FUND}_{\mathrm{t}+1}$ should be positive and significant. If both estimates are positive and significant, then there exists a bi-directional relationship. In unreported results, we find that the estimate for $F U N D_{t}$ is positive and significant but it is not for $\mathrm{FUND}_{t+1}$. Hence, the results support the conjecture that mutual fund investors invest in a firm and press it to disclose IC information.

\section{Conclusion}

Using a unique data set from the SSE during the period 2006-2010, we examine the determinants and/or incentives for a firm's voluntary IC-disclosure decision, as well as its decision additionally to have an auditor's attestation on the IC report. We hypothesize and find supporting evidence that a firm with the government, especially the central government, as its largest shareholder, with more mutual fund shareholding, and with an equity refinancing plan in the near future, is more likely to disclose an IC self-assessment report and to attain an auditor's attestation on the report.

Our study contributes incrementally to the literature in several ways. Firstly, we study not only the determinants of voluntary disclosure of IC information, but also the determinants of voluntarily having an auditor's attestation on the IC report. The decision to have an auditor's attestation on an IC report is important, especially in developing countries, as it can further enhance the credibility of the report. Secondly, our finding that an IC report with an auditor's attestation can facilitate seasoned-equity issuing is also new in the literature. Our study shows that credible and voluntary disclosure of IC self-assessment has some signaling effect in the market. Thirdly, our sample includes firms with IC weaknesses. This allows us to address the identification problem that previous studies have not addressed. Our finding is that mutual-fund investors have a positive impact on the credible disclosure of IC reports even when the firm has shown IC weakness. This is an affirmation that mutual funds can play a role in enhancing effective corporate governance. It is also an affirmation of the efforts on the part of the CSRC to develop a mutual-fund industry in China.

\section{Endnotes}

${ }^{1} \mathrm{IC}$ disclosure in the Shenzhen Stock Exchange is mandatory, as all firms listed there have been required by law to disclose IC information, such as selfassessment, since 2007. This is different from the IC legal environment in the Shanghai Stock Exchange.

${ }^{2}$ For cross-listed firms, mandatory disclosure of self-assessment started in 2011. An auditor's attestation on IC reports has also been mandatory since 2012.

${ }^{3}$ See, for example, Chen et al. (2009), and Huang et al. (2011).

${ }^{4}$ The shares of listed firms were divided into tradable shares and non-tradable shares before the completion of the share segmentation reform in 2006; tradable shares accounted for only one-third of total shares before 2006. Other financial 
institutional investors are the National Pension Fund and insurance companies. However, their investments in the stock market are much smaller than the holdings of mutual funds during our sample period and they are also subject to many restrictions. Hence, we do not consider them in our study.

${ }^{5}$ They are the Ministry of Finance (MOF), the National Audit Office, and all three major industry regulators: the China Securities Regulatory Commission (CSRC), the China Banking Regulatory Commission (CBRC) and the China Insurance Regulatory Commission (CIRC).

${ }^{6}$ Source: RESSET Database.

${ }^{7}$ See footnote 8 .

${ }^{8}$ For example, an article by Wang Shengke appeared in The Market Daily criticizing the 12 largest government-controlled listed companies with monopolistic power in their respective industries. These companies paid generous salaries and awarded lavish fringe benefits to their employees. According to Wang, the China National Oil Corporation (CNOC) paid RMB120k per employee in 2006, while the national average was only around RMB20k. At the same time, CNOC cited increasing international oil prices to justify its gasoline-price hike (The Market Daily, July 14th 2007). Li Shizhong, the chairman of the supervisory board on large SOEs, pointed out that many SOE managers were engaged in tunneling which resulted in a serious loss of state assets (see China Economic News, 2003, No. 12, p. 38).

${ }^{9} 815$ observations in 2006, 830 observations in 2007, 834 observations in 2008,836 observations in 2009, and 857 observations in 2010.

${ }^{10} \mathrm{~A}$ legitimate question is who decides what information constitutes weakness? We do think it involves some subjective judgment and may vary across firms. However, it should be safe to assume that, on average, the IC quality should be worse for those who report IC weaknesses than for those who do not.

${ }^{11}$ For example, Zhuhai Boyuan Investment Co., Ltd. stated in 2010 that there were deficiencies in its IC system which should be amended. Shanghai Jinqiao Export Processing Zone Development Co., Ltd. disclosed in 2010 that it was short of internal auditing staff and its fixed asset accounting is inaccurate.

${ }^{12}$ In this study, we run all logistic regressions with clustered standard errors using the programming advice from Professor Mitchell A. Petersen's website, which is available at the link below: http://www.kellogg.northwestern.edu/faculty/ petersen/htm/papers/se/se_programming.htm.

${ }^{13}$ In terms of audit fees charged, the share for the Big4 is on average about $50 \%$ during our sample period.

${ }^{14} \mathrm{We}$ use long-term debt over equity rather than total liability over total assets as an alternative proxy for LEV; the results are qualitatively similar.

${ }^{15}$ Results are not reported to save space but available upon request from the authors.

${ }^{16}$ Again this finding is robust when we replace GOV*SEO with CENTRAL"GOV*SEO. The results are not reported to save space.

${ }^{17}$ The marginally insignificant estimate for FUND may be due to the small sample size.

${ }^{18}$ The results are not reported to save space.

${ }^{19}$ The results are not reported to save space. 


\section{Appendix}

Table 7 Description of variables

\begin{tabular}{ll}
\hline Variable name & Description \\
\hline ICVD $=$ & ICVD in Model 1 is set 1 if a firm discloses an IC self-assessment report, and zero otherwise. In \\
& Model 2 all non-disclosures are deleted. Then ICVD is set to 1 if a firm attains an auditor's \\
attestation on the IC self-assessment report, and zero otherwise. ICVD in Model 3 is categorized \\
into three groups: ICVDO represents firms with no IC self-assessment report at all, which serves \\
as the benchmark; ICVD1 represents firms with only an IC self-assessment report; and ICVD2 \\
represents firms with both an IC self-assessment report and an auditor's attestation. Since \\
ICVD0 is used as the benchmark, we replace ICVD with ICVD1 and set it equal to 1 if the firm \\
is in the category of ICVD1, and zero otherwise. Similarly, we replace ICVD with ICVD2 and set \\
it equal to 1 if the firm is in the category of ICVD2.
\end{tabular}

\section{Acknowledgements}

We would like to thank Steven Wang, Clive Lennox, Charles Chen, Yaw Mensah, Linda Myers, Yue Heng and workshop participants at Beijing University, Nanjing University, Fudan University, University of International Business and Economics, California State University at Northridge, the Chinese Accounting Professors Association of North American annual conference, and the AAA annual meeting for helpful comments. We acknowledges the financial support of the National Natural Science Foundation of China (No. 71172035, 71272074 and 71572046).

\section{Authors' contributions}

All authors have read and approved the final manuscript.

\section{Competing interests}

The authors declare that they have no competing interests.

\section{Publisher's Note}

Springer Nature remains neutral with regard to jurisdictional claims in published maps and institutional affiliations.

\section{Author details}

${ }^{1}$ School of Economics, Shanghai University of Finance and Economics, Shanghai 200433, China. ${ }^{2}$ School of Management, Fudan University, Shanghai 200433, China. 
Received: 3 January 2017 Accepted: 22 March 2017

Published online: 05 June 2017

\section{References}

Bronson, N. S., Carcello, J. V., \& Raghunandan, K. (2006). Firm characteristics and voluntary management reports on internal control. Auditing: A Journal of Practice and Theory, 25(2), 25-39.

Chen, K. C., \& Yuan, H. (2004). Earnings management and capital resource allocation: evidence from China's accountingbased regulation of rights issues. The Accounting Review, 79(3), 645-666.

Chen, X., Lee, C., \& Li, J. (2008). Government assisted earnings management in China. Journal of Accounting and Public Policy, 27(3), 262-274

Chen, G., Firth, M., \& Xu, L. (2009). Does the type of ownership control matter? Evidence from China's listed companies. Journal of Banking and Finance, 33(1), 171-181.

Cheung, Y., Rau, P. R., \& Stouraitis, A. (2010). Helping hand or grabbing hand? Central vs. local government shareholders in Chinese listed firms. Review of Finance, 14, 669-694.

Dechow, P. M., Sloan, R. G., \& Sweeney, A. P. (1996). Causes and consequences of earnings manipulation: an analysis of firms subject to enforcement actions by the SEC. Contemporary Accounting Research, 13(Spring), 1-36.

Deumes, R., \& Knechel, W. R. (2008). Economic incentives for voluntary reporting on internal risk management and control systems. Auditing: A Journal of Practice and Theory, 27(1), 35-66.

Fang, HX, Sun, H, Jin, YY. 方红星，孙翯，金韵韵 (2009). 公司特征，外部审计与内部控制信息的自愿披露一基于沪市 上市公司2003-2005年年报的经验研究 (Corporate characteristics, external audit, and voluntary disclosure of internal control information: An empirical study based on annual reports of listed companies of Shanghai Stock Exchanges from 2003 to 2005). 会计研究 (Accounting Research), 10, 44-52.

Healy, P. M., \& Palepu, K. G. (2001). Information asymmetry, corporate disclosure, and the capital markets: a review of the empirical disclosure literature. Journal of Accounting and Economics, 31, 405-440.

Hermanson, H. (2000). An analysis of the demand for reporting on internal control. Accounting Horizons, 4(3), 325-341.

Huang, J., Shen, Y., \& Sun, Q. (2011). Non-negotiable shares, controlling shareholders, and dividend payments in China. Journal of Corporate Finance, 17(1), 122-133.

Jiang, G., Lee, C., \& Yue, H. (2010). Tunneling through inter-corporate loans: the China experience. Journal of Financial Economics, 98, 1-20

Kinney, W., \& McDaniel, L. (1989). Characteristics of firms correcting previously reported quarterly earnings. Journal of Accounting and Economics, 11, 71-93.

Leone, J. A. (2007). Factors related to internal control disclosure: a discussion. Journal of Accounting and Economics, 44, 224-237.

Lin, B, Rao, J. 林斌，饶静 (2009). 上市公司为什么自愿披露内部控制鉴证报告?一基于信号传递理论的实证研究 (Why do listed companies disclose the auditor's internal control reports voluntarily? An empirical study based on signaling theory in China.) 会计研究, (Accounting Research), 8(2), 45-52.

Lin, YF, Liu, MX, Zhang, Q. 林毅夫, 刘明兴，章奇 (2004). 政策性负担与企业的预算软约束: 来自中国的实证研究 (Policy burdens and the soft-budget constraint: Evidence from China.) 管理世界(Management World), (8), 81-89.

Mei, J, Scheinkman, J, Xiong, W (2005). Speculative trading and stock prices: An analysis of Chinese A-B share premia. Working paper, New York University, New York.

Myers, S. C., \& Majluf, N. S. (1984). Corporate financing and investment decisions when firms have information that investors do not have. Journal of Financial and Economics, 13(2), 187-222.

Petersen, M. A. (2009). Estimating standard errors in finance panel data sets: comparing approaches. Review of Financial Studies, 22(1), 435-480.

Sun, Q., Tong, W., \& Wu, Y. (2013). Overseas listing as a policy tool: evidence from China's H-shares. Journal of Banking \& Finance, 37(1), 460-474.

Yu, Q., Du, B., \& Sun, Q. (2006). Earnings management at rights issues thresholds: evidence from China. Journal of Banking \& Finance, 30(3), 453-468.

Zeng, QS, Chen, XY. 曾庆生, 陈信元 (2006). 国家控股, 超额雇员与劳动力成本 (Government control, excess employees, and labor cost). 经济研究 (Economic Research), 5, 74-86.

\section{Submit your manuscript to a SpringerOpen ${ }^{\circ}$ journal and benefit from:}

- Convenient online submission

- Rigorous peer review

- Open access: articles freely available online

- High visibility within the field

- Retaining the copyright to your article

Submit your next manuscript at $>$ springeropen.com 